\title{
RECONCEPTUALISING EUCHARIST AS SUBSERVIENT RITUAL: \\ A MISSIOLOGICAL RESPONSE TO PUBLIC VIOLENCE IN AFRICA
}

\author{
People Came to Mass Each Day to Pray,
} Then They Went Out to Kill (WCC 1994:778)

Chammah J Kaunda ${ }^{1}$

Christian Spirituality

University of South Africa

\begin{abstract}
In this article, I argue that the church as Christ's symbolic presence in the world is a Missiological expression of God loving non-violent involvement and witnessing presence in the world permeated with violence. Through two case studies that exemplify the relationship between public speech and public violence - the 1994 Rwandan genocide and the 2015 xenophobic attacks in South Africa - the article demonstrates the potential of liminality of Eucharistic encounter to inspire and empower African Christians prophetically to respond non-violently to the plague of public violence in many African countries.
\end{abstract}

Key Words: Public Speech; Missiological; Public Violence; 1994 Rwandan Genocide; 2015 South African Xenophobia; Eucharist; Liminality

\section{Introduction}

It appears easier to imagine the end of the world today than the total elimination of violence in postcolonial Africa ${ }^{2}$. The nature of contemporary conflict violence ${ }^{3}$ in Africa poses profoundly disturbing questions: How do people who are alike in almost every way learn to see one another as enemies? What makes people become convinced that they should kill their innocent neighbours? What force is so strong as to mobilize large numbers of people to engage in conflict violence? How do so many people become easily bewitched by mere

Chammah J Kaunda (PhD) is Postdoctoral Research Fellow in Christelike Spiritualiteit/Christian Spirituality of Universiteit van Suid-Afrika/University of South Africa, Pretoria. He is particularly interested in how African Religio-Cultural Heritage can inform African Theology Christianity, Politics, Theological Education, African Pentecostal Theology, Missiology and Ecumenical Theology.

2 In this study, 'Africa' and its adjective 'African', unless specified refers to the black people of Buntu ancestry occupying the Sub-Saharan continent.

3 There is an influx of edited volumes, all trying to develop theories of violence in postcolonial Africa: such as Adebayo Adedeji (ed.) (1999), Comprehending and Mastering African Conflicts; Jean Comaroff and John L Comaroff (eds.) (2006), Law and Order in the Postcolony; Alfred Nhema and Patrick Zeleza (eds.) (2008), The Roots of African Conflicts; Patrick Chabal Ulf Engel and Anna-Maria Gentili (eds.), Is Violence Inevitable in Africa? Pal Ahluwalia, Louise Bethlehem and Ruth Ginio (eds.) (2007), Violence and NonViolence in Africa and many others. 
'words' of an individual and engage in such despicable violence? To what extent does the public speech contribute to public violence in Africa? How can Missiological praxis facilitate African Christian response to public violence?

This article has two main intentions: first to show the ways in which public $\operatorname{speech}^{4}$ in public spheres ${ }^{5}$ of those who have socio-political authority is entangled with the logic and pervasiveness of public violence in some African societies. This is achieved through examining two case studies on recent xenophobic attacks in South Africa and genocidal hatred of Tutsis in Rwanda. The second is to suggest the ways in which African Christians can respond missiologically to public violence.

\section{Prophetic Witness to Public Violence: A Missiological Praxis}

In this context of pervasive conflict violence, the task of missiology is to enable African churches to re-examine missiologically their social constitutions and realign them with its Missiological calling through mediation of the Holy Spirit. The mission of God in the world is a mission of life. It originates in the heart of the interpersonal relational Triune God as an overflow of unconditional love and the life that binds the Holy Trinity to all humanity and creation, as antidote against violence and injustice. In his What is Mission? (2000:28), Andrew Kirk writes "The mission of God flows directly from the nature of who God is ... God's intention for the world is that in every respect it should show forth the way he is - love, community, equality, diversity, mercy, compassion and justice." This resonates with David Bosch's (2011/1991:10) earlier assertion in Transforming Mission, that mission is an attribute of God and a radical "participation in God's existence in the world." This means that "The Church is commissioned to celebrate life," as Jooseop Keum (ed.) (2013:4) argues, "through resisting and transforming all life destroying forces, in the power of the Holy Spirit."

The mission of the Triune God on earth was epitomised through Christ's violent public death on the cross which unveiled once and for all the logic of mimetic violence since the dawn of humanity. By refusing to engage in a vengeful cycle of violence, Jesus critiqued the language of violence promoted through religious and political structures by which public violence is fomented. It unveils that violence can never be an instrument to bring about socio-political and economic transformation. The violent death of Jesus on the cross reveals a God who reconciles the world to himself by rejecting violence as means for bringing peace into the world. Rather, he absorbed all forms of human violence in his body. In dying on the cross Jesus turned upside down the logic of violence through absorption "within himself the power of sin, death, and violence and then destroyed them" (Cameli 2012:90). God detests violence, but chooses to undergo violence, to reveal God's great love for the world (Mt. 26:52 - "Put your sword back in its place," Jesus said to him, "for all

4 In this article, unless specified, public speech refers to any utterance to any particular audience either through media or public gatherings. These are public speeches from authoritative speakers, endowed with specific socio-political authority which explicitly or implicitly mediate and justify violence ideologically. Sabelo J Ndlovu-Gatsheni (2012) and Slavoj Žižek (2009) refers to the violence embedded in the public speech (words and language) as 'symbolic'. This violence "exists like the dark matter of physics, and are the motive force of" (Ndlovu-Gatsheni 2012:421) "what otherwise seem to be 'irrational' explosions of subjective violence" (Žižek 2009:2).

5 In this article the concept of " "public sphere' refers to a set of physical or mediated spaces where people can gather and share information, debate opinions, and tease out their political interests and social needs with other participants" (Squires 2002:448). These spaces are never neutral but highly contested. 
who draw the sword will die by the sword."). Here we see Jesus extending peace to his enemies. It shows that only genuine love can triumph over violence. By choosing to become a victim of human injustice and violence, Jesus reveals the God who does not abandon humanity in the brokenness of injustice but suffers with them as they search for the ways of overcoming injustice and violence through the efficacy of the Holy Spirit.

The Holy Spirit is a Trinitarian or Triune Spirit who witnesses to the paradox of Christ's resistance to violence and yet dying a violent death on the cross in order to reconcile the world to God. The Spirit of God offers resistance against violence and destruction of life. In his The Spirit of Life, Jürgen Moltman (1992:xi) argues that the efficacy of the Spirit is universal "and ministers to life and resists its destruction." The significance of missiology of the Spirit is captured by Amos Yong (2014:230), who argues that "pneumato-missiology does not rely on Christians having or exercising political authority but on their capacity to promote the healing reconciliation essential to a peaceful, just, and beautiful world order." It requires believers to stand in the face of violence and death as the affirmation of life. It is through radical affirmation of life that the Church experiences the Holy Spirit. In other words, the Church's missional response to violence and injustice is effective only when it 'is informed by' what Yong (2014:225) calls, 'pneumatological intuitions.' In this way, the Spirit of God inspires and empowers the Church to witness to violence and injustice in the world through rearticulating certain aspects of their doctrines or theology in order to make them responsive to the context of the Church's engagement. This is called prophetic reconfiguration. The mission of God as prophetic resistance to violence means that the Church creatively renovates and upgrades its theological resources to enable her to discern and openly reject potential violent symbols, signs, speeches, movies, sculptures, cartoons, children's toys, video games, references, rhythms and actions within public spaces by calling to account those who are directly involved and exposing them for what they are. This also involves a struggle to fight the fetters of poverty, socio-political injustice, economic exploitation, gender inequality, capitalism and consumerism. In this way, Missiological praxis brings an interface between Christian faith and existential realities. This is significant in the search for ways of overcoming violence which is an indispensable aspect of the mission of the Spirit in the world. To show the pertinence of violence in the mission in African societies the following section discusses two case studies to show the pervasive of public violence and how it is entwined with the logic of public speech.

\section{The Public Discourse and Ethno- and Xenophobia: Two Case Studies}

The aim of this section is to demonstrate concisely how public speech foments public violent conflicts in African countries and serves as means for self-identification, articulation of grievances, verbalisation of existential challenges and definition of some form of expectations for uncertain futures.

\section{'The Tutsi-phobia': The Hutu Power Discourse}

On 6 April 1994 the plane carrying the Rwandan president Juvénal Habyarimana and Burundian president Cyprien Ntaryamira was shot down over Kigali airport, killing everyone on board. In the aftermath, Rwanda erupted into one of the most horrendous cases of mass murder the world has witnessed since World War II. The majority ethnic group in Rwanda, the Hutus (about 85 percent) descended on the Tutsi (who were only about 12 percent of the population) and the moderate Hutu. The genocide was perpetrated over the course of a hundred days, during which an estimated total of 800000 Tutsi and moderate 
Hutu were systemically attacked, robbed, raped and murdered (Longman 2010; Katongole 2009; Grunfeld and Huijboom 2007; Kuperman 2001). In the aftermath, scholars considered what kind of force could instigate ordinary (including Christian) Hutus to commit such atrocious crimes against neighbours who had done nothing to them.

The answer to the question is complex, but one reason was given by a former Génocidaires who was influenced by the Hutu anti-Tutsi public speeches. In the early 1990s most Hutu power public speeches were implicit and vague. But in November 1992 Leon Mugusera, the Gisenyi MRND vice-president, made a public extremist speech to over 1000 people that would reverberate throughout the whole country because of its Tutsiphobic content. He denounced the Tutsis and the opposition parties as follows:

Cockroaches talking to other cockroaches ... exterminate this scum! ...What are we waiting for to execute the sentences? ... What are we waiting for to decimate these families? ... Destroy them. No matter what you do, do not let them get away ... The fatal mistake we made in 1959 was to let them get out ... They belong in Ethiopia and we are going to find them a shortcut to get there by throwing them into the Nyabarongo River ... We have to act. Wipe them all out (Adelman and Suhrke (eds.) 1999:77). ${ }^{6}$

This speech was distributed on cassettes to the Hutus throughout Rwanda. During the same period, the Hutu extremists acquired control of the mass media. In the early 1990s, 66 percent of the Rwandan population was illiterate; 29 percent of households had radios, and large populations listened to the radio in public places (Mann 2005:444). The anti-Tutsi Rwandan radio station, the Radio-Television Libre des Mille Collines (RTLM) in Kigali, began broadcasting on 8 July 1993. The station closed just after the genocide on 31 July 1994 (Kuperman 2001). This génocidaires radio became an epicentre for propagating Tutsiphobic speeches. It is important to remember that the radio functioned in the context that was experiencing enormous socio-political frustrations and resentment. Hutu youth faced a situation where many had no land, no jobs, little education, and no hope for the future. Mamdani (2001:51) writes of drastic economic decline in the late 1980s and early 1990s as well as the 'massive corruption' in the government. He observes (2001:146) that by the end of the 1980s, "the World Bank was citing Rwanda as one of the three worst performing sub-Saharan countries when it came to food production." In contrast to the majority of Hutu who were experiencing disgraceful socio-economic conditions, the Tutsi were in a seemingly economically more advantageous position during this period. Mamdani (2001) argues that the apparent privileged economic status of the Tutsi could have been easy to objectify and construct in colonial terms as privileged colonialists taking away their jobs, exploiting their economy and relegating the Hutu to perpetual impoverishment.

This is evident in the argument of the former Génocidaires who stressed that the public speeches were used as means for constructing the Tutsis not just as the other but objectifying them as things - 'cockroaches' - which could easily be killed without remorse. He narrates that "they kept saying Tutsis were cockroaches" (Timmermann 2005:258). The Hutu extremists preached the gospel of the "oppressed against the oppressors, but included all Tutsi, regardless of social class, in the latter category" (Morrock 2010:65). The Hutu ideology which begun as ethnic consciousness, affirming "intrinsic worth of being Hutu," the "need to follow a moral Christian life," and the "uselessness of politics which should be replaced by hard work" (Morrock 2010:66), progressed into ethnocentric ideology or 'Tutsi-phobia' (Bamurangirwa 2013:60). It promoted a Hutu mind-set in which ethnic-

6 The same quotation can also be found in Mann (2005:444), Rucyahana (2007:57) and Verwimp (2013:127). 
chauvinism and Tutsi hatred was verbalised and normalised as a political ideology. "The division of Hutu and Tutsi entrenched fear and suspicion of the Tutsi and fabricated the perception that the Tutsi population had to be destroyed in order to safeguard the political gains that had been made by the Hutu majority" (Timmermann 2005:270).

Wibke Timmermann (2010:266, 276) argues that the distinction must be made between the "discussion of ethnic consciousness and the promotion of ethnic hatred". For instance, the RTLM broadcast declared that the Tutsi:

"...are the ones who have all the money." They were constantly portrayed as "ruthless killers who have it in their nature to murder" and this meant that "pre-emptive action to avoid such killing" was regarded as the only choice ... further enhanced by the media's persistent warnings of Tutsi 'infiltration' of the economy, their monopolisation of credit at the banks, and their alleged taking of a disproportionate share of all kinds of desirable professions.

This kind of propaganda is often engendered as Philip Gourevitch (1998:66, see also Morrock 2010:66) argues by "a deep, almost mystical sense of inferiority which persisted among Rwanda's new Hutu elite..." Thus, the public speeches were used as means of "political indoctrination that demonised the Tutsi and convinced many Hutu that Tutsi elimination was the country's economic and political remedy" (Magnarella 2002:34). Political indoctrination used the pretence of self-protection to call for extermination:

RTLM broadcast a message of fear ... and encouraged [listeners] to defend and protect themselves, incessantly telling them to 'be vigilant', which became a coded term for aggression in the guise of self-defence (Timmermann 2005:269).

The International Tribunal for Rwanda (ICTR) concluded that if downing the plane triggered genocide in Rwanda, then public speeches "were the bullets in the gun. The trigger had such a deadly impact because the gun was loaded" (Timmermann 2005:270).

The Rwandan genocide happened 21 years ago but is connected to the recent xenophobic violence in South Africa by the role public speech played in instigating people to xenophobic violence.

\section{The King's Speech and South African Xenophobia}

In the deadly xenophobic violence of April 2015, the King of the Zulu people ${ }^{7}$ of KwaZuluNatal, Goodwill Zwelithini was implicated as inciting public violence against African foreign nationals in South Africa. In a public speech in Pongola, northern KwaZulu-Natal, the King stated:

[W]e talk of people [South Africans] who do not want to listen, who do not want to work, who are thieves, child rapists and house breakers.... When foreigners look at them, they will say let us exploit the nation of idiots. As I speak you find their unsightly goods hanging all over our shops, they dirty our streets. We cannot even recognise which shop is which, there are foreigners everywhere. I know it is hard for other politicians to challenge this because they are after their votes. Please forgive me but this is my responsibility, I must talk, I cannot wait for five years to say this. As king of the Zulu nation ... I will not keep quiet when our country is led by people who have no opinion. It is time to say something. I ask our government to help us to fix our own problems, help us find our own solutions. We ask foreign nationals to pack their belongings and go back to their countries (Time Live 2015, see also De Vos 2015).

7 The Zulu people are one of the most dominant ethnic groups in South Africa. 
I am not trying to demonstrate whether these remarks can be classified as hate speech as defined in the Equality Act of the Constitution of South Africa. But Pierre de Vos (2015), a South African constitutional law scholar, has demonstrated from a Constitutional Law perspective that "in the context which the words were uttered it is difficult to avoid the conclusion that the King would be found guilty of hate speech if charged." In his speech, the king diagnosed the problem in contemporary South Africa as twofold: laziness among locals and foreigners making dirty the streets. He then proposed a remedy as "foreign nationals (legally or illegal) to pack their belongings and go back to their own countries." But the king does not show how the deportation of foreigners will cure the perceived pathological laziness. What these remarks seem to demonstrate is an entrenched xenophobia in the king to such an extent that he puts the words in the mouths of the foreigners: "they [foreigners] will say let us exploit the nation of idiots." President Jacob Zuma's eldest son, Edward Zuma, supported the king's remarks, stressing that "we [South Africans] need to be aware that as a country we are sitting on a ticking time bomb of them [foreigners] taking over the country" (City Press 2015).

Some people believe that the king's statement may be blamed for the xenophobic violence that erupted in parts of KwaZulu-Natal, spread to Gauteng and left at least seven people dead and thousands displaced. On the contrary, the king argued that the remarks he made in the Zulu language were misinterpreted, claiming that he only called for the repatriation of illegal immigrants. He argued that the media chose "to deliberately distort what was an innocent outcry against crime and destruction of property" (City Press 2015). He argued further that if he had given orders to kill foreign nationals "this country [South Africa] would be reduced to ashes" (The Guardian 2015). This stance is defended by Prince Mangosuthu Buthelezi, a politician and Zulu tribal leader who founded the Inkatha Freedom Party (IFP). He argued that "regardless of how one interprets what his majesty said, one thing is clear. He never decreed violence, mayhem, looting, murder or arson" (The Guardian 2015).

Contrary to this, The Socio-economic Rights and Accountability Project (Serap) (cited in City Press 2015) argues that the statement cannot be justified under any law. It is classified as 'hate speech' which "generated fear and hatred that created the conditions for violence and discrimination against Nigerians and other African citizens." Serap (cited in City Press 2015) further stresses that too often crimes against humanity are followed by speeches such as the king's, "once the climate of violence has been created, direct and public incitement to crimes builds on it, exacerbating the situation by further heating up passions and directing South Africans' hatred towards African foreign nationals." Ralph Mathekga (2015:1), a political analyst, feels that "while xenophobic attacks may subside and totally dissipate, the sentiments and hatred against the foreign nationals will remain. All that it takes for the hatred to ignite into open violence is just another episode of frustration." In an interview, the Wits University researcher Jean-Pierre Misago (cited in Eye Witness News 2015) stated that such a statement cannot be easily quoted out of context or be lost in translation as defended. He stressed that the issue of xenophobia is complex because "even people high up in the government share the same feelings as people in the street and when those pronouncements come from the political and country leaders, people on the ground take them as a directive."

As observed above, the context in which the speech arose is similar to the socioeconomic conditions in which anti-Tutsi speeches found fertile ground. King Zwelithini's public speech emerged in the context of political frustration and dissatisfaction which 
makes his audience (which was grassroots majority) vulnerable to his remarks. Current studies of the pathway to genocide have demonstrated how remarks such as the one from the king are poisonous to the minds of a socio-economically and politically frustrated population (Mann 2005; Verwimp 2003; Andre and Platteau 1998; Longman 1995). Any public speech with socio-economic implications - when directed against any particular group of people - can be construed as calling for economic reversal through the mechanism of public violence. The growing frustrations of some black South Africans living in poverty, witnessing economic exploitation and leadership crises have created a volatile atmosphere where any form of public speech can easily be misconstrued as a directive for engaging in public violence. In most cases, it is not what is said that matters but who says it, the way it is said, and to whom it is said. During Adolf Hitler's reign Nazi fascism antiSemitic speeches found fertile ground in repressed feelings of socio-economic frustrations and fear of weakness (Morrock 2010).

The foregoing discussion shows that public violence in Africa is a Missiological challenge as it is not only perpetuated by those outside the Church but by members of the Church as well. As a comparative analysis of the link between poisonous public speeches and violent conflicts, unfortunately reveals, genocide in Rwanda and xenophobic attacks in South Africa are neither irreplaceable nor mysterious, but rather phenomena that are too common in many postcolonial African societies and in most of these violent conflicts, Christians are among the perpetrators (Katongole 2009). Mamdani (2001:226), a Muslim scholar, categorised the Church in Rwanda as an "epicenter that radiated violence." How can a Missiological framework help African Christians to reconceptualise Eucharistic encounters missiologically as ritual of subversion against human violence?

\section{Eucharistic Ritual of Subservience against Human Violence}

If churches had prepared their members for the possibility of poisonous public speeches in the two case studies referred to above, would it have made a difference? I cannot tell. What appears clear is that the aftermath of these violent conflicts unveils how the African Church is - as Luther King, Jr. (1963) noted - "largely adjusted to the status quo, standing as a taillight behind other community agencies rather than a headlight leading [humanity] to higher levels of justice." It shouts and prophecies in the aftermath of tragedies of violence to readjust back to the status quo once some form of calm appears.

The quotation from the World Council of Churches (WCC 1994:778) above appears to suggest that some individuals who engage in public violence in most African countries are or were adherents of the Christianity, who may have participated in one way or another in Eucharistic encounter with the Lord Jesus Christ. I have decided to utilise Eucharistic encounter as prophetic resistance against human violence because it is one of the sacraments that is practiced equally in all Christian traditions. I will draw some resources from cultural liminality to demonstrate how Eucharistic encounter can function as a catharsis space and Missiological conscientisation for prophetic resistance against human violence. The Eucharistic encounter happens in a space separated from the normative social order.

In his famous book, The Rites of Passage, Arnold van Gennep (1960/1908) outlines a threefold mnemonic phase which defines every ritual process. The liminal participants (Eucharistic partakers) go through a transition period which always begins with separation from social normality and moves into the liminal space to encounter the Lord and get reintegrated into normal society, to live out and demonstrate God's unconditional love in 
and for the world. The focus of this section is on the stage of liminality, a notion which British anthropologist Victor Turner $(1967,1969)^{8}$ rediscovered in the works of Van Gennep. Turner witnessed that during ritual performances the initiates are often isolated from social structural spaces and traditionally spent a lengthy period in anti-structural and temporary spaces, which Van Gennep classified as a liminary state. The liminal participants are considered 'no longer/not yet' or both 'dead and living' - "neither here nor there; they are betwixt and between the positions assigned and arrayed by law, custom, convention, and ceremonial" (Turner 1969:95). Turner describes this as the stage of being between phases. The liminal entities are neither in the ordinary social spaces nor outside them; they are betwixt and between. They are neither living nor dead; they are both sinners and righteous, experience both hatred and love and are both violent and non-violent. This is the ambiguity of the anti-structural period. They are all treated equally as pure spirits or holistic beings with no hierarchy and receive instructions only from their liminal guardian(s). The significance of liminal experiences depends partly on their difference from social normal realities. In the liminal, power and privilege, status and role, law and institution no longer determine social relations. The only thing they are subjected to is the holy teaching of Jesus Christ. It is a time outside of time and space outside space or timeless time and spaceless space where alternative identities and subjectivities are constructed and new modalities of liminal relations appear. Johan Cilliers $(2009: 25,2013: 1)^{9}$ notes that the "liminal experience is filled with potential and creativity, but also with risk and danger." Turner calls this new model of relationship a communitas (must be distinguished from community) - characterised by equality, immediacy and the lack of social ranks and roles. Jeffrey Rubenstein (1992:251) sees the liminal as "a levelling process [which] brings about the dissolution of structure, the absence of social distinctions, a homogenisation of roles, the disappearance of political allegiance, the breakdown of regular borders and barriers. With the suspension of status distinctions, human beings recognise the core humanity they share." The struggle of every liminal participant is to realise his/her humanity - a humanity which is perceived as always becoming more and more like Jesus (Roman 8; 2 Cor. 3). The liminal stage is significant for the formation of social bond and experience of interrelatedness.

This is how the rite of Eucharist functions as a liminary stage. It is a movement from social structures plagued by daily violence into the space where the believers can symbolically experience and re-experience injustice, violence, death through contemplating and participation in the Eucharist and thereafter symbolically experience and re-experience rebirth, regenerative renewal and empowerment to re-enter normal society to bear witness for non-violence through lifestyle and actions of resistance to violence. The argument here is that when believers encounter God through Eucharist, they also encounter their inner violence and generic violence in the world. Louis Cameli (2012:91) observes that "although our Eucharistic setting may be tranquil and undisturbed, we know that the Eucharist is a sacrament" wrought through violence and death of an innocent human being. It is a ritual of reconciliation for the estranged human beings. This is a table on which human violence is poured on Jesus who alone can absorb its destruction in his body. Kevin Kelly $(2005: 25)^{10}$ argues that the remembrance "in Eucharist is keeping alive the memory of a bloody and

\footnotetext{
8 Victor Turner discusses in detail the meaning of liminality using empirical evidence from the Ndembu people of Zambia.

9 In these two studies Johan Cilliers gives a detailed discussion of the link between liminality and Eucharist.

10 Kevin Kelly gives a full discussion which demonstrates the interplay between Eucharist and violence.
} 
cruel act of violence. 'Do this in memory of me' commits the Christian Church and every Christian to never forgetting a horrendous act of violence against the person of the one whom they believe to be the Son of God." This re-enactment of remembering human violence is a form of catharsis that is meant to enable Eucharistic participants to vent their inner rage, anger and violence unto the one who bears human pain, injustice and violence.

The foregoing shows that the rite of Eucharist is essentially the rite of passage from violence and estrangement to reconciliation, unconditional acceptance and unconditional love. Therefore, those who participate in the Eucharist have the right to know the nature of human violence and injustice and how these have resulted in fundamental alienation of human beings from one another, creation and God. In participating in the Eucharist, believers are called to re-enact in their lives and the world, injustice and violence that take a daily toll on human life (Cameli 2012). It confronts believers with the reality of deep wounds and divisions of human struggles. It presents the enduring violence and injustice in the world, which is a source of distress, poverty, terrorism, ecological crisis, Ebola, HIV and AIDS, gender injustice and inequality, rape, civil wars, religious violence, ethnicity, racism, greediness, xenophobia, corruption, capitalism, consumerism and many other lifedestroying forces, which all bear witness to the devastation of human violence. The Eucharistic liminal encounter with Jesus, the violence bearer, the peacemaker and reconciler, empowers believers to make a fresh commitment to work with the Spirit of life for the full liberation of human consciousness from violence. The continuous separation from normal society and re-enactment of violence through Eucharist and constant reincorporation into the general society means that Eucharistic participants can be relentlessly and consistently exhorted, reminded, re-empowered, reinspired and reinvigorated to struggle over and over again to develop a lifestyle of non-violence by implementing nonviolent behaviour in their own lives, families, communities and in all walks of life. The communitas - the bond of trust and interrelatedness formed as a result of incessant encountering and re-encountering one another through the liminal reigns of Eucharist - also means that they are accountable and have a responsibility to challenge one another to radical peace and a non-violent lifestyle. This is a testimony to the world searching for peace and a resistance to prevailing violence in the social order (Ephesians 4:15-16; Colossians 3:9-10).

\section{Conclusion}

In conclusion: I have used two case studies - the 1994 Rwandan genocide and the 2015 xenophobic attacks in South Africa - to demonstrate the interplay between poisonous public speech performance and public violence that occur in many African countries. I have also suggested the Missiological reconceptualisation of Eucharist as a ritual of subservience against human violence to encourage re-enactment of violence in the liminal spaces where Jesus absorbs within himself violence. This approach to Eucharist has potential for catharsis and promotion of a changed lifestyle, behaviour and attitude for both individual and public violence.

\section{BIBLIOGRAPHY}

Adelman, Howard and Astri Suhrke (eds.) 1999. The Path of Genocide: the Rwanda Crisis, from Uganda to Zaire. Uppsala: Nordiska Afrikainstitutet. 
André, Catherine, Jean-Philippe Platteau 1998. "Land Relations under Unbearable Stress: Rwanda caught in the Malthusian Trap," Journal of Economic Behavior \& Organization 34/1:1-47.

Bamurangirwa, Patrick 2013. Rwanda Yesterday. Leicestershire: Matador.

Bayart, Jean-François, Stephen Ellis, Béatrice Hibou 1999. The Criminalization of the State in Africa. Oxford: James Currey \& Indiana University Press.

Benson, B Ellis, Malinda E Berry, Peter G Heltze (eds.) 2012. Prophetic Evangelicals: Envisioning a Just and Peaceable Kingdom. Grand Rapids, MI: William B Eerdmans.

Berkeley, Bill 2001. The Graves are not Yet Full: Race, Tribe and Power in the Heart of Africa. New York, NY: Basic Books.

Bosch, David J 2011/1991. Transforming mission: Paradigm Shifts in Theology of Mission, $20^{\text {th }}$ Anniversary edition. New York: Orbis.

Cameli, Louis J 2012. Bread of Life: Exploring the Presence of Eucharist in Our Lives. Chicago: Liturgy Training Publications.

Chabal, Patrick, Ulf Engel, Anna-Maria Gentili (eds.) 2005. Is Violence Inevitable in Africa? Theories of Conflict and Approaches to Conflict Prevention. Leiden and Boston: Brill.

Cilliers, Johan H 2009. "Worshipping in the 'in-between' Times of Transition: Reflections on the Liminality of Liturgy," in Pieterse H \& C Thesnaar (eds.). A Faithful Witness: Essays in Honour of Malan Nel. Wellington: Bybel Media, 167-179.

Cilliers, Johan H 2013. "Between Fragments and Fullness: Worshipping in the in-between Spaces of Africa," HTS Teologiese Studies/Theological Studies 69/2:1-6.

City Press, 2005. "King Zwelithini's 'xenophobic' remarks 'lost in translation," http://www.citypress.co.za/news/king-zwelithinis-xenophobic-remarks-lost-intranslation/. [Accessed 29 April 2015.]

City Press, 2005. "Xenophobia: ICC gets Hate-speech Complaint against King Zwelithini," http://www.citypress.co.za/news/xenophobia-icc-gets-hatespeech-complaint-againstking-zwelithini/. [Accessed 29 April 2015.]

Comaroff, Jean, John L Comaroff (eds.) 2006. Law and Disorder in the Postcolony. Chicago and London: The University of Chicago Press.

De Vos, Pierre 2015). "Xenophobic Statement: Is King Zwelithini Guilty of Hate Speech? http://constitutionallyspeaking.co.za/xenophobic-statement-is-kingzwelithini-guiltyof-hate-speech/"'. [Accessed 29 April 2015.]

Eye Witness News, 2015. "Zulu King Faces More Criticism over Controversial Comments," http://ewn.co.za/2015/04/16/Zulu-Kings-comments-taken-to-task. [Accessed 29 April 2015.]

Fanon, Frantz 1963. The Wretched of the Earth. London: Penguin.

Gourevitch, Philip 1998. We Wish to Inform You that Tomorrow We Will Be Killed with Our Families. New York: Picador.

Grunfeld, Fred, Anke Huijboom 2007. The Failure to Prevent Genocide in Rwanda: The Role of Bystanders. Leiden/Boston: Martinus Nijhoff Publishers.

Katongole, Emmanuel M 2009b. Mirror to the Church: Resurrecting Faith after Genocide in Rwanda. Grand Rapids: Zondervan. 
King, Martin L Jr. 1963. "Letter from the Birmingham Jail," http://www.stanford.edu/group /King/Docs/birmingham.html. [Accessed 14 Aug. 15.]

Kuperman, Alan J 2001. The Limits of Humanitarian Intervention: Genocide in Rwanda. Washington, DC: Brookings Institution Press.

Longman, Timothy 1995. "Genocide and Socio-Political Change: Massacres in Two Rwandan Villages," Issue: A Journal of Opinion, 23/2:18-21.

Longman, Timothy 2010. Christianity and Genocide in Rwanda. Cambridge: Cambridge University Press.

Magnarella, Paul 2002. "Explaining Rwanda's 1994 Genocide," Human Rights \& Human Welfare, 2:1:25-34.

Mamdani, Mahmood 2001. When Victims Become Killers: Colonialism, Nativism, and the Genocide in Rwanda. Princeton, NJ: Princeton University Press.

Mann, Michael 2005. The Dark Side of Democracy. Cambridge: Cambridge University Press.

Mathekga, Ralph 2015. "Political Power Vs Monarch," Press Reader: 1 FrontPage. http://www.pressreader.com/south-africa/the-new-age-free-state. [Accessed 29 April 2015.]

Moltmann, Jürgen 1992. The Spirit of Life: A Universal Affirmation, trans. Margaret Kohl. London: SCM Press.

Morrock, Richard 2010. The Psychology of Genocide and Violent Oppression: A Study of Mass Cruelty from Nazi Germany to Rwanda. Jefferson, North Carolina, and London: McFarland \& Company, Inc.

Ndlovu-Gatsheni, Sabelo J 2012. "Beyond the Equator There Are No Sins: Coloniality and Violence in Africa," Journal of Developing Societies 28/4:419-440.

Nhema Alfred and Patrick T Zeleza (eds.) 2008. The Roots of African Conflicts: The Causes and Costs. Addis Ababa: OSSREA, Oxford: James Currey, Athens: Ohio University Press and Pretoria: UNISA Press.

Rubenstein, Jeffrey 1992. "Purim, Liminality, and Communitas," AJS Review, 17/2:247-277.

Rucyahana, John 2007. The Bishop of Rwanda. Tennessee: Thomas Nelson.

Squires, Catherine R 2002. "Rethinking the Black Public Sphere: An Alternative Vocabulary for Multiple Public Spheres, ” Communication Theory, 12/4:446-468.

The Guardian, 2015. "Zulu leader suggests media to blame for South Africa's xenophobic violence," http://www.theguardian.com/world/2015/apr/20/south africa-xenophobicviolence-zulu-king-goodwill-zwelithini. [Accessed 29 April 2015.]

Thompson, Allan (ed.) 2013. The Media and the Rwanda Genocide. London: Pluto.

Times Live, 2015. "Listen to exactly what King Goodwill Zwelithini said about foreigners," http://www.timeslive.co.za/local/2015/04/16/listen-to-exactlywhat -king-goodwillzwelithini-said-about-foreigners. [Accessed 29 April 2015.]

Timmermann, Wibke K. 2005. "The Relationship between Hate Propaganda and Incitement to Genocide: A New Trend in International Law towards Criminalization of Hate Propaganda?" Leiden Journal of International Law, 18:257-282.

Turner, Victor W 1967. The Forest of Symbols: Aspects of Ndembu ritual. Ithaca, N.Y.: Cornell University Press. 
Turner, Victor W 1969. The Ritual Process: Structure and Anti-structure. Ithaca, N.Y.: Cornell University Press.

Townsley, Jeramy 2003. "Rene Girard's Theory of Violence, Religion and the Scapegoat." www.jeramyt.org/papers/girard.html [accessed 14 Aug. 15].

Van Gennep, Arnold. 1960/1908. The Rites of Passage. Chicago: University of Chicago Press.

Verwimp, Philip. 2013. Peasants in Power: The Political Economy of Development and Genocide in Rwanda. Dordrecht: Springer.

Verwimp, Philip 2003. "An Economic Profile of Peasant Perpetrators of Genocide: Microlevel evidence from Rwanda," Journal of Development Economics, 77/2:297-323.

WCC 1994. "Rwandan Churches Culpable, says WCC," Christian Century, 111/24:778

Yanagizawa-Drott, David 2014. "Propaganda and Conflict: Evidence from the Rwandan Genocide," The Quarterly Journal of Economics, 129/4:1947-1994.

Yong, Amos 2014. The Missiological Spirit: Christian Mission Theology in the Third Millennium Global Context. Eugene, Ore. Cascade Books.

Young, Crawford 1994. The African Colonial State in Comparative Perspective. New Haven: Yale University Press.

Žižek, Slavoj 2009. Violence: Six Sideways Reflections. London: Profile Books. 